\title{
STRATEGI PEMASARAN DESA BRAJAN MENUJU DESA WISATA MANDIRI
}

\author{
MARKETING STRATEGY FOR BRAJAN VILLAGE TO BE INDEPENDENT TOURISM VILLAGE
}

\author{
Ivo Novitaningtyas*), Andhatu Achsa*), dan Budi Rahardjo*11 \\ *) Program Studi Manajemen, Fakultas Ekonomi, Universitas Tidar \\ J1. Kapten Suparman No.39, Magelang, Jawa Tengah, 56116, Indonesia
}

\begin{abstract}
The objective of this research is to identify the existing business model implemented by Brajan Tourism Village by using Business Model Canvas (BMC) approach in order to develop a new business model after being analyzed by the SWOT analysis. SWOT analysis uses to identify the condition of internal factors based on the marketing mix of services and the conditions of external factors based on economic, environmental, political, socio-cultural, and technological conditions. The result shows that the condition of this tourism village has many strengths and some opportunities that have not been utilized. Thus, the formulation of strategies that can be applied is SO strategy, such as developing tourism products according to tourist interest trends, collaborating with tourism influencers as a promotion tool through social media, and increasing the quality and quantity of tourist facilities. The strategy should be implemented to develop a new business model for the Brajan Tourism Village in order to become an independent tourism village.
\end{abstract}

Keywords: tourism village, marketing strategy, SWOT, business model canvas, Brajan

\begin{abstract}
Abstrak: Tujuan penelitian ini adalah untuk mengidentifikasi kondisi bisnis wisata dari Desa Wisata Brajan saat ini melalui pendekatan Business Model Canvas (BMC) untuk kemudian mengembangkan model bisnis baru setelah dianalisis menggunakan analisis SWOT. Analisis SWOT dilakukan untuk mengetahui kondisi faktor internal berdasarkan bauran pemasaran jasa dan kondisi faktor eksternal berdasarkan kondisi ekonomi, lingkungan, politik, sosial budaya, dan teknologi. Hasil analisis menunjukkan bahwa kondisi desa wisata ini memiliki banyak kekuatan dan beberapa peluang yang belum dimanfaatkan. Dengan demikian, rumusan strategi yang bisa diterapkan adalah strategi SO yaitu mengembangkan produk wisata sesuai tren minat wisatawan, bekerjasama dengan tokoh panutan sebagai sarana promosi melalui media sosial, serta meningkatkan kualitas dan kuantitas fasilitas wisata. Strategi tersebut diterapkan untuk mengembangkan model bisnis baru bagi Desa Wisata Brajan dalam rangka menuju desa wisata yang mandiri.
\end{abstract}

Kata kunci: desa wisata, strategi pemasaran, SWOT, business model canvas, Brajan

${ }^{1}$ Alamat Korespondensi:

Email: budi.rahardjo@untidar.ac.id 


\section{PENDAHULUAN}

Pariwisata menjadi salah satu sektor yang terus dikembangkan di Indonesia karena telah terbukti memberikan dampak positif. Beberapa manfaat dari pengembangan pariwisata yaitu menciptakan lapangan kerja, meningkatkan kesejahteraan masyarakat, dan meningkatkan pendapatan bagi perekonomian daerah (Departemen Kebudayaan dan Pariwisata, 2009; Ernawati et al. 2017). Salah satu wujud pengembangan pariwisata adalah pengembangan desa sebagai objek wisata. Beberapa tahun terakhir, desa wisata menjadi destinasi populer pada beberapa negara di Asia dan Eropa (Ciolac et al. 2017). Keberadaan desa wisata memberikan peluang bisnis di bidang pariwisata bagi masyarakat setempat serta meningkatkan pendapatan mereka (Ciolac et al. 2017).

Desa wisata adalah salah satu objek wisata pedesaan yang menawarkan atraksi wisata, menyediakan akomodasi, dan memiliki fasilitas pendukung lainnya (Triyanto et al. 2018). Pariwisata berbasis pedesaan memiliki karakteristik alam dan budaya yang unik dan berpotensi menjadi daya tarik wisata bagi wisatawan (Susyanti, 2013; Triyanto et al. 2018). Wisatawan tidak hanya sekedar menikmati atraksi yang ditawarkan, tetapi juga ikut mengenal, belajar, dan mengapresiasi karakteristik masyarakat setempat. Tipe wisatawan yang merupakan potensi pasar bagi desa wisata yaitu wisatawan mancanegara, wisatawan pelajar, dan wisatawan yang memiliki motivasi untuk mempelajari budaya masyarakat setempat. Tipe wisatawan tersebut cenderung memiliki kesadaran untuk menjaga lingkungan pedesaan, menghargai budaya masyarakat setempat, dan bersedia berinteraksi dengan masyarakat setempat (Giampiccoli dan Saayman, 2018).

Kabupaten Sleman sebagai salah satu daerah tujuan wisata di Indonesia juga turut serta mengembangkan desa wisata. Kabupaten Sleman memiliki 49 desa wisata yang diklasifikasikan sebagai 9 desa wisata mandiri, 8 desa wisata berkembang, 14 desa wisata tumbuh, dan 8 desa wisata tidak berkembang (Dinas Kebudayaan dan Pariwisata, Ludens Tourism Space, dan STARS, 2016). Desa wisata juga diklasifikasikan berdasarkan basis potensinya menjadi desa wisata berbasis alam seperti agro wisata dan ekowisata serta desa wisata berbasis budaya yang meliputi kerajinan, adat istiadat dan sejarah (Dinas Kebudayaan dan Pariwisata, Ludens Tourism Space, dan STARS, 2016). Sedangkan menurut Hamzah dan Irfan (2018), desa wisata dibagi menjadi 3 kategori berdasarkan Tourism Life Cycle dan Product Life Cycle yaitu kategori desa wisata potensial, desa wisata berkembang, dan desa wisata unggul. Dinas Kebudayaan dan Pariwisata, Ludens Tourism Space, dan STARS (2016) menjelaskan bahwa potensi, atraksi, amenitas, aksesibilitas, dan pemasaran menjadi beberapa indikator yang menentukan kemajuan desa wisata. Para pemangku kepentingan dalam hal ini yaitu Pemerintah dan pengelola berharap agar seluruh desa wisata yang sudah dibentuk bisa tumbuh, berkembang, dan menjadi desa wisata yang mandiri.

Brajan merupakan salah satu desa wisata kategori berkembang yang terkenal sebagai sentra kerajinan bambu di Kabupaten Sleman. Desa wisata ini menjadi salah satu desa wisata berbasis budaya, selain Desa Wisata Gamplong. Desa Wisata Gamplong sudah menjadi desa wisata kategori mandiri, sedangkan Desa Wisata Brajan masih dalam tahap berkembang (Dinas Kebudayaan dan Pariwisata, Ludens Tourism Space, dan STARS, 2016) dan diharapkan dapat menjadi desa wisata mandiri. Berdasarkan hal tersebut diperlukan identifikasi potensi Desa Wisata Brajan agar mampu menjadi desa wisata mandiri di Kabupaten Sleman.

Identifikasi potensi pemasaran terdiri dari bagaimana produk dan potensi pengembangan produk, berapa harga yang ditetapkan, siapa saja saluran distribusinya, dan bagaimana promosi dilakukan (Abam, 2016). Identifikasi terhadap potensi pasar dan ancaman kompetitor juga perlu dilakukan. Dengan demikian, diharapkan Desa Wisata Brajan dapat mengidentifikasi potensi pemasaran yang dimiliki untuk dikembangkan, serta permasalahan yang dihadapi agar ditemukan solusinya. Lebih lanjut, Kurniasih et al. (2018) mengemukakan bahwa desa wisata perlu mempertimbangkan unsur-unsur di dalam pemasaran seperti segmen pasar, paket wisata sebagai produk yang ditawarkan kepada pasar, cara mempromosikannya, serta pengembangan potensi dan atraksi lainnya menjadi produk baru, agar menjadi destinasi wisata yang berhasil.

Analisis SWOT merupakan analisis terhadap faktor kekuatan (Strenght), kelemahan (Weakness), peluang (Opportunity), dan ancaman (Threat). Analisis ini digunakan untuk mengidentifikasi faktor internal dan eksternal dari suatu perusahaan atau organisasi. Faktor internal yaitu kekuatan dan kelemahan, 
sedangkan faktor eksternal yaitu peluang dan ancaman. Hasil dari identifikasi tersebut digunakan untuk merumuskan strategi. Melalui analisis ini, perusahaan atau organisasi dapat memaksimalkan kekuatan, memanfaatkan peluang, meminimalkan kelemahan, dan menekan dampak ancaman yang dihadapi. Lebih lanjut, Zhang (2012) menjelaskan bahwa melalui analisis SWOT peneliti juga dapat menemukan solusi bagi permasalahan yang dihadapi perusahaan atau organisasi, dan membuat arah kebijakan bagi pengembangan perusahaan atau organisasi di masa depan.

Penggunaan analisis SWOT sebagai alat untuk mengidentifikasi potensi dan permasalahan dalam merumuskan strategi juga dapat diterapkan pada pengembangan desa wisata (Dharasta et al. 2017; Kusrini, 2017; Mustika dan Aditya, 2018; Nasehi dan Allahyari, 2017; Pramanik dan Widyastuti, 2017; Vladi, 2014; Widyaningsih, 2016; Zhang, 2012). Analisis SWOT juga digunakan sebagai alat untuk mengidentifikasi kondisi pemasaran dalam menentukan strategi pemasaran pada perusahaan atau organisasi tertentu (Kotler dan Keller, 2018; Noor, 2014). Zhang (2012) menjelaskan bahwa tahapan analisis SWOT terdiri dari menganalisis faktor internal berupa kekuatan dan kelemahan, dan menganalisis faktor eksternal berupa peluang dan ancaman. Melalui analisis ini, dapat diketahui potensi pemasaran yang perlu dikembangkan dan permasalahan apa yang dihadapi oleh desa wisata.

Desa wisata sebagai salah satu usaha jasa pariwisata di bidang destinasi memerlukan rencana bisnis (business plan). Business Model Canvas merupakan metode yang digunakan untuk melihat kondisi suatu usaha bisnis dan memberikan gambaran rencana bisnis selanjutnya. Pengelola bisnis dapat melihat perkembangan kondisi bisnisnya melalui pemetaan pada sebuah kanvas saja. Hal tersebut menjadi kelebihan metode ini dibanding metode lainnya. Business Model Canvas terdiri dari beberapa elemen, yaitu (1) Customer Segment, (2) Value Proposition, (3) Channel, (4) Customer Relationship, (5) Revenue Stream, (6) Key Resources, (7) Key Activity, (8) Key Partnership, dan (9) Cost Structure (Koswaraputra et al. 2019; Rahardjo et al. 2019). Hal ini dapat diterapkan di desa wisata untuk melihat kondisi perkembangan bisnis pariwisatanya. Dengan demikian diharapkan memberikan gambaran bagi pengelola untuk merumuskan strategi bisnis menuju desa wisata mandiri.
Penelitian terdahulu menggunakan analisis SWOT untuk mengidentifikasi faktor internal dan eksternal desa wisata untuk merumuskan strategi pemasaran yang tepat (Andajani et al. 2017). Nasehi dan Allahyari (2017) telah merumuskan strategi untuk pengembangan desa wisata menggunakan analisis SWOT yang fokus terhadap identifikasi faktor-faktor ekonomi. Adapun penelitian lainnya fokus pada identifikasi faktorfaktor berupa elemen daya tarik, aksesibilitas, sarana informasi, dan akomodasi (Pramanik dan Widyastuti, 2017). Selain itu, penelitian serupa pernah dilakukan terhadap desa wisata di Kabupaten Sleman secara menyeluruh untuk merumuskan strategi meningkatkan jumlah kunjungan wisatawan di desa wisata (Dharasta et al. 2017). Lebih lanjut, Widyaningsih (2016) telah mengidentifikasi potensi produk sebagai dasar merumuskan strategi pengembangan Desa Wisata Brajan menggunakan analisis SWOT. Walaupun demikian, identifikasi yang dilakukan hanya terbatas pada produk kerajinan saja, dan belum mencakup faktor pemasaran lainnya. Selain itu, penelitian tentang penerapan Business Model Canvas pada desa wisata belum pernah dilakukan sebelumnya. Berdasarkan hal tersebut, perlu dilakukan identifikasi faktor-faktor pemasaran yang meliputi produk, harga, saluran distribusi, promosi, proses, bukti fisik, dan people dari sisi internal (kekuatan dan kelemahan), kondisi eskternal (peluang dan ancaman) melalui analisis SWOT, serta implementasi Business Model Canvas. Hasil penelitian ini dapat dijadikan pedoman bagi pemangku kepentingan (Pemerintah Kabupaten Sleman dan pengelola Desa Wisata Brajan) untuk merumuskan strategi pemasaran dan menetapkan langkah-langkah menuju desa wisata mandiri.

\section{METODE PENELITIAN}

Penelitian dilakukan di Desa Wisata Brajan Kabupaten Sleman. Kegiatan penelitian dilakukan selama 3 bulan. Pelaksanaanya yaitu pada bulan Juni-Agustus 2019. Lokasi penelitian ditentukan secara purposive dengan pertimbangan bahwa Desa Wisata Brajan adalah salah satu desa wisata budaya di Kabupaten Sleman yang termasuk dalam kategori berkembang.

Jenis data yang digunakan dalam penelitian ini adalah data primer dan data sekunder. Data primer diperoleh secara langsung dari narasumber yaitu Pokdarwis (Kelompok Sadar Wisata) Desa Wisata Brajan. Selain itu data primer juga diperoleh melalui hasil observasi 
untuk melihat kondisi secara langsung pada objek penelitian. Adapun data sekunder diperoleh dari literatur seperti jurnal, buku, dan laporan pemerintah dalam hal ini Laporan Kegiatan Klasifikasi Desa Wisata oleh Dinas Pariwisata Kabupaten Sleman.

Data yang digunakan dalam penelitian ini diperoleh berdasarkan teknik pengumpulan data yaitu wawancara, observasi, serta studi dokumentasi. Wawancara dilakukan kepada Pokdarwis (Kelompok Sadar Wisata). Observasi dilakukan dengan mengamati proses produksi dan konsumsi paket wisata di Desa Wisata Brajan, fasilitas yang tersedia, serta kondisi aksesibilitas. Adapun studi dokumentasi dilakukan untuk memperoleh data sekunder.

Penelitian ini adalah penelitian deskriptif dimana Business Model Canvas dan SWOT diterapkan untuk menggambarkan kondisi objek penelitian dan merumuskan strategi yang sesuai. Data yang telah terkumpul diidentifikasi berdasarkan 9 elemen Business Model Canvas untuk menganalisis kondisi saat ini. Selanjutnya dilakukan analisis SWOT untuk menghasilkan strategi yang sesuai diterapkan pada pengembangan model bisnis yang baru dalam rangka menuju desa wisata mandiri. Adapun kerangka penelitian dapat dilihat pada Gambar 1.

\section{HASIL}

Desa Brajan adalah desa wisata kategori berkembang di Kabupaten Sleman yang berbasis kebudayaan berupa kerajinan tangan dari bambu. Potensi wisata sentra kerajinan bambu yang menjadi ciri khas tersebut diharapkan dapat mengembangkan Desa Brajan menjadi desa wisata mandiri. Sebagai objek wisata, desa ini sudah memiliki 6 komponen yaitu atraksi, amenitas, aksesibilitas, harga, sumber daya manusia, dan citra. Desa Wisata Brajan memiliki komponen daya tarik wisata yang lengkap terdiri dari something to see, something to do, dan something to buy. Desa ini menawarkan pemandangan alam pedesaan yang bisa dinikmati oleh wisatawan (something to see). Beberapa aktivitas wisata seperti outbond dan belajar membuat kerajinan tangan dari bambu menjadi paket wisata utama yang ditawarkan kepada wisatawan (something to do). Adapun produk kerajinan tangan dari bambu menjadi cinderamata yang bisa dibeli oleh wisatawan (something to buy). Amenitas dan fasilitas yang tersedia terdiri dari penginapan, toilet umum, dan area parkir. Adapun aksesibilitas menuju desa ini juga mudah dijangkau. Lebih lanjut, komponen harga juga sudah disusun dan ditawarkan kepada wisatawan secara detail melalui tiket masuk dan paket wisata. Selain itu, desa ini juga sudah memiliki pengelola dan kelompok sadar wisata (pokdarwis) sebagai komponen sumber daya manusia. Desa Wisata ini memiliki citra sebagai desa wisata berbasis budaya.

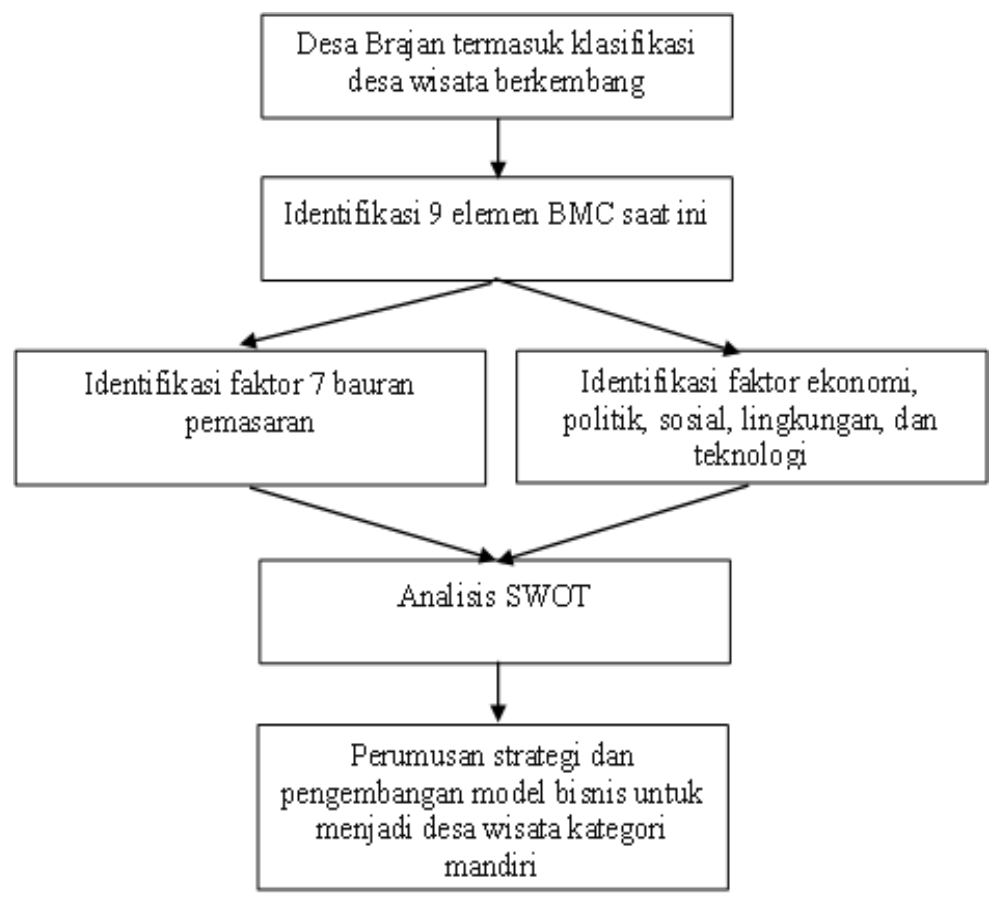

Gambar 1. Kerangka pemikiran penelitian 


\section{Business Model Canvas Saat Ini}

Gambar 2 menunjukkan kondisi bisnis yang divisualisasikan melalui matriks BMC. Perkembangan bisnis Desa Wisata Brajan sebagai desa wisata atau objek wisata saat ini dianalisis berdasarkan 9 elemen BMC. Elemen yang diidentifikasi yaitu customer segments, value propositions, channels, customer relationship, revenue streams, key activities, key resources, key partnership, dan cost structure. Hasil identifikasi diuraikan sebagai berikut:

Customer Segments: Segmen pasar dari Desa Wisata Brajan terdiri dari wisatawan domestik maupun asing. Wisatawan yang berkunjung ke objek wisata ini berupa FIT (Free Individual Traveler) dan group. Selama perkembangannya, wisatawan yang menjadi pelanggan berasal dari segmen domestic group berupa grup pelajar, grup mahasiswa, dan grup MICE (Meeting,
Incentive, Conference, dan Exhibition) dalam hal ini berupa insentif dari perusahaan atau organisasi tertentu. Untuk wisatawan mancanegara didominasi oleh wisatawan dari Eropa (Belanda, Italia, Inggris, Spanyol, dan Perancis).

Value Propositions: Sebagai salah satu objek wisata, Desa Wisata Brajan sudah memiliki elemen dasar destinasi wisata yaitu atraksi, aksesibilitas, dan fasilitas. Nilai daya tarik (attraction) yang dimiliki desa wisata ini terdiri dari 3 jenis yaitu something to see, something to do, dan something to buy. Wisatawan dapat menikmati keindahan pemandangan alam pedesaan (something to see). Wisatawan juga dapat belajar membuat kerajinan tangan dari bambu dan melakukan aktifitas outbond (something to do). Selain itu, wisatawan dapat membeli produk kerajinan tangan dari bambu sebagai cinderamata (something to buy).

\begin{tabular}{|c|c|c|c|c|}
\hline \multirow[b]{2}{*}{$\begin{array}{l}\text { Key partners: } \\
\text {-Dinas Pariwisata } \\
\text { Kabupaten } \\
\text { Sleman } \\
\text {-Jasa Raharja }\end{array}$} & $\begin{array}{l}\text { Key activities: } \\
\text {-Perencanaan layout } \\
\text { alam pedesaan } \\
\text {-Pembuatan kerajinan } \\
\text { bambu } \\
\text {-Pelatihan pembuatan } \\
\text { kerajinan bambu } \\
\text {-Kegiatan outbond }\end{array}$ & \multirow{2}{*}{$\begin{array}{l}\text { Value Propositions: } \\
\text {-Something to see (suasana alam } \\
\text { pedesaan yang asri) } \\
\text {-Something to do (edukasi } \\
\text { pembuatan kerajikan bambu, } \\
\text { sensasi outbond di alam pedesaan) } \\
\text {-Something to buy (kerajinan } \\
\text { bambu) } \\
\text {-Akses yang mudah } \\
\text {-Fasilitas memadai }\end{array}$} & $\begin{array}{l}\text { Costomer } \\
\text { - Relationships: } \\
\text {-Layan sosial } \\
\text {-Layan grup } \\
\text { (pemandu) }\end{array}$ & \multirow{2}{*}{$\begin{array}{l}\frac{\text { Cusotemr }}{\text { Segments: }} \\
\text {-Domestik } \\
\text { (pelajar, } \\
\text { mahasiswa, } \\
\text { grup, MICE) } \\
\text {-Asing/ } \\
\text { mancanegara }\end{array}$} \\
\hline & $\begin{array}{l}\text { Key Resources: } \\
\text {-Tangible (lahan } \\
\text { pedesaan, bangunan } \\
\text { pendukung, SDM, } \\
\text { bahan baku alami, } \\
\text { sumber daya } \\
\text { keuangan) } \\
\text {-Intangible (budaya } \\
\text { masyarakat, } \\
\text { keterampilan } \\
\text { membuat kerajinan } \\
\text { bambu) }\end{array}$ & & $\begin{array}{l}\text { Channels: } \\
\text {-Biro Perjalanan } \\
\text { Wisata }\end{array}$ & \\
\hline \multicolumn{2}{|c|}{$\begin{array}{l}\text { Cost Structure: } \\
\text {-Biaya operasional } \\
\text {-Upah tenaga kerja } \\
\text {-Biaya pemasaran } \\
\text {-Biaya pengembangan } \\
\text {-Biaya perawatan } \\
\text {-Biaya pembuatan kerajinan bambu }\end{array}$} & & \multicolumn{2}{|c|}{$\begin{array}{l}\text { Revenue Streams: } \\
\text {-Penjualan paket wisata } \\
\text {-Penjualan tiket masuk kawasan wisata } \\
\text {-Jasa akomodasi } \\
\text {-Penjualan souvenir }\end{array}$} \\
\hline
\end{tabular}

Gambar 2. Business Model Canvas Desa Wisata Brajan 
Channels: Desa Wisata Brajan bekerja sama dengan biro perjalanan wisata sebagai saluran distribusinya. Desa wisata ini menjadi salah satu objek yang dikunjungi wisatawan melalui paket wisata Biro Perjalanan Wisata (BPW). Biro perjalanan wisata rekanan mendatangkan wisatawan yang kemudian menjadi pelanggan bagi desa wisata ini.

Customer Relationship: Desa wisata ini menjalin hubungan dengan wisatawan melalui media sosial dan layanan grup. Desa wisata Brajan berkomunikasi dengan wisatawan melalui online social media. Beberapa akun social media yang digunakan adalah Facebook dan Instagram. Pengelola mengunggah foto disertai informasi tentang desa wisata untuk dibagikan kepada wisatawan melalui social media tersebut. Adapun layanan grup dilaksanakan bagi wisatawan saat mengunjungi desa wisata ini. Wisatawan dibagi menjadi beberapa kelompok untuk mengikuti kegiatan sesuai paket wisata yang dipilih. Relasi antara tuan rumah (host) dan tamu (guest) terjalin saat pelaksanaan layanan grup.

Revenue Streams: Pendapatan desa wisata ini diperoleh dari penjualan produk wisata seperti penjualan paket wisata, penjualan tiket masuk taman wisata, penjualan jasa penginapan (homestay), penjualan jasa makanan dan minuman (food and beverage), dan penjualan produk kerajinan tangan dari bambu (souvenir).

Key Activities: Desa Wisata Brajan melakukan beberapa aktivitas untuk menciptakan nilai (value) yang ditawarkan kepada wisatawan. Aktivitas tersebut terdiri dari perencanaan dan tata layout kawasan desa, pembuatan kerajinan bambu, pelatihan pembuatan kerajinan bambu, dan aktivitas outbond. Melalui aktivitas tersebut dihasilkan produk wisata berupa tata letak fasilitas dan sebaran homestay dan produk kerajinan bambu sebagai cinderamata bagi wisatawan.

Key Resources: Sumber daya di Desa Wisata Brajan dibedakan berdasarkan sifatnya yaitu tangible dan intangible. Sumber daya yang tergolong tangible terdiri dari lahan pedesaan, bangunan, sumber daya manusia, bahan baku alami, dan sumber daya keuangan, sedangkan yang bersifat intangible berupa kebudayaan masyarakat dan keterampilan yang dimiliki masyarakat untuk membuat kerajinan bambu.
Key Partnerships: Desa Wisata Brajan menjalin kerjasama dengan beberapa rekanan yaitu Dinas Pariwisata Kabupaten Sleman dan Jasa Raharja. Dinas Pariwisata Kabupaten Sleman berperan dalam memberikan pelatihan dan pembimbingan secara periodik bagi pengelola desa wisata. Jasa Raharja adalah rekanan yang membantu pengembangan taman bunga di desa wisata ini. Selain itu, Desa Wisata Brajan juga menjadi desa binaan dari Jasa Raharja.

Cost Structure: Adapun biaya yang dibutuhkan untuk menjalankan aktivitas di Desa Wisata Brajan terdiri dari biaya operasional dan biaya pemasaran. Biaya operasional meliputi biaya untuk perawatan taman bunga, biaya listrik dan air untuk homestay, biaya bahan makanan dan minuman untuk diolah, biaya upah sumber daya manusia, serta biaya bahan baku pembuatan kerajinan tangan. Sedangkan untuk biaya pemasaran digunakan untuk promosi melalui media sosial.

\section{Analisis SWOT}

Tabel 1 menunjukkan matriks SWOT. Analisis SWOT digunakan untuk menganalisis faktor eksternal dan internal dari Desa Wisata Brajan. Faktor internal terdiri dari strenghts dan weaknessess yang dianalisis berdasarakan unsur 7 bauran pemasaran (product, price, place, promotion, people, physical evidence, dan process). Faktor eksternal terdiri dari opportunities dan threats yang dianalisis berdasarkan faktor kondisi ekonomi, politik, sosial, lingkungan, dan teknologi. Hasil rumusan strategi selanjutnya diimplementasikan pada Business Model Canvas. Berikut penjelasan dari faktor internal dan eksternal:

Strenghts: Desa Wisata Brajan memiliki beberapa kekuatan yaitu produk yang unik dan proses yang berbasis pengalaman (experience based tourism). Adapun kekuatan dari segi fisik dibuktikan dengan aksesibilitas yang mudah dari pusat Kota Yogyakarta maupun dari gerbang masuknya wisatawan (tourism gate) seperti bandar udara, stasiun dan terminal. Desa wisata ini juga sudah bekerjasama dengan beberapa biro perjalanan wisata rekanan sebagai saluran distribusinya. Pengelola juga sudah memanfaatkan kemajuan teknologi dan internet sebagai sarana promosi melalui online social media. 


\begin{tabular}{|c|c|c|}
\hline Faktor Eksternal & $\begin{array}{l}\text { Stenghts (S) } \\
\text { 1. Produk wisata unik } \\
\text { 2. Bekerja sama dengan BPW } \\
\text { sebagai saluran distribusi } \\
\text { 3. Sudah memiliki akun media sosial } \\
\text { sebagai alat promosi } \\
\text { 4. Aksesibilitas terjangkau\&ada } \\
\text { fasilitas pendukung }\end{array}$ & $\begin{array}{l}\text { Weaknesess }(\mathbf{W}) \\
\text { 1. Harga setara dengan pesaing } \\
\text { 2. SDM belum memiliki } \\
\text { keterampilan bahasa asing } \\
\text { 3. Belum mengembangkan proses } \\
\text { pelayanan wisata }\end{array}$ \\
\hline $\begin{array}{l}\text { Opportunities (O) } \\
\text { 1. Kredit Usaha Rakyat sebagai } \\
\text { alternatif pembiayaan } \\
\text { 2. Dukungan pemerintah melalui } \\
\text { PP No. } 12 \text { Tahun } 2019 \text { tentang } \\
\text { Pengelolaan Keuangan Daerah, } \\
\text { dan Kementerian Pariwisata \& } \\
\text { Dinas Pariwisata Kabupaten } \\
\text { Sleman melalui Rakornas } \\
\text { Pariwisata II/2017 } \\
\text { 3. Perkembangan tren gaya hidup ke } \\
\text { arah experience based tourism dan } \\
\text { mengikuti tokoh panutan } \\
\text { 4. Perkembangan teknologi } \\
\text { (penerapan pada sektor } \\
\text { transportasi, dan perkembangan } \\
\text { jenis-jenis media sosial) }\end{array}$ & $\begin{array}{l}\text { Strategi SO } \\
\text { 1. } \begin{array}{l}\text { Mengembangkan produk wisata } \\
\text { sesuai trend minat wisatawan }\end{array} \\
\text { (S1,S5\&O3,O4) } \\
\text { 2. Memberdayakan tokoh panutan } \\
\text { (influencer) sebagai sarana } \\
\text { promosi melalui media sosial } \\
\text { (S3,S2\&O3) } \\
\text { 3. Peningkatan kualitas \& kuantitas } \\
\text { sarana prasarana pendukung } \\
\text { (S4\&O1,O2) }\end{array}$ & $\begin{array}{l}\text { Strategi WO } \\
\text { 1. Menerapkan strategi harga } \\
\text { bersaing (W1\&O2) } \\
\text { 2. Sosialisasi dan pelatihan kepada } \\
\text { SDM terkait keterampilan bahasa } \\
\text { asing \& pengelolaan desa wisata } \\
\text { (W2\&O2) }\end{array}$ \\
\hline $\begin{array}{l}\text { Threats }(\mathbf{T}) \\
\text { 1. Gagal bayar Kredit Usaha Rakyat } \\
\text { 2. Kondisi lingkungan, fenomena } \\
\text { alam \& bencana alam } \\
\text { 3. Kompetitor }\end{array}$ & 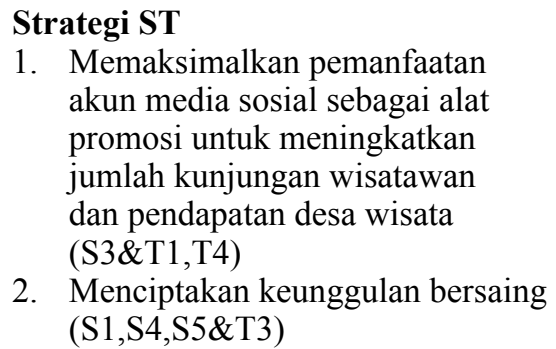 & $\begin{array}{l}\text { Strategi WT } \\
\text { 1. Melakukan inovasi terhadap } \\
\text { proses pelayanan, menyediakan } \\
\text { alternatif jika kondisi cuaca tidak } \\
\text { mendukung (W3\&T2) }\end{array}$ \\
\hline
\end{tabular}

Weaknesses: Walaupun Desa Wisata Brajan memiliki beberapa unsur kekuatan, tetapi desa wisata ini juga memiliki kelemahan. Kelemahan tersebut terlihat dari harga produk wisata yang cenderung setara dengan desa wisata lainnya di Kabupaten Sleman. Selain itu pengelola desa wisata memiliki mata pencaharian utama yang beragam, sehingga pengelolaan terhadap desa wisata belum menjadi prioritas. Lebih lanjut pengelola desa juga memiliki kelemahan dari sisi keterampilan yaitu kurang menguasai bahasa asing. Adapun dari segi proses, desa wisata ini belum melakukan pengembangan maupun inovasi terhadap proses pelayanan wisata kepada wisatawan.

Opportunities: Secara eksternal terdapat beberapa peluang yang dapat diberdayakan oleh Desa Wisata Brajan. Desa wisata dapat memanfaatkan Kredit Usaha Rakyat (KUR) sebagai sumber alternatif pembiayaan. Dari sektor pemerintahan terdapat peluang seperti adanya regulasi yang mengatur tentang pengelolaan keuangan daerah termasuk pajak dari retribusi pariwisata dan usaha pariwisata (PP No. 12 Tahun 2019 tentang Pengelolaan Keuangan Daerah). Selain itu, kebijakan dari hasil Rakornas Pariwisata II/2017 tentang pengembangan desa wisata dan homestay desa wisata menjadi salah satu peluang yang dapat dimanfaatkan sebagai bentuk dukungan dari pemerintah terkait. Lebih lanjut, perkembangan tren gaya hidup masyarakat ke arah experience based tourism menjadi peluang dari sisi sosial dan budaya. Wisatawan cenderung tertarik pada destinasi wisata yang menawarkan produk wisata berbasis pengalaman. Dengan demikian wisatawan tidak hanya sekedar mengunjungi destinasi tetapi juga mendapat edukasi dari kunjungan tersebut dan berinteraksi dengan penduduk lokal. Teknologi juga merupakan faktor eskternal yang menciptakan peluang bagi desa wisata. Kemajuan teknologi di bidang transportasi seperti aplikasi transportasi berbasis internet menjadi peluang karena memudahkan aksesibilitas wisatawan 
menuju desa wisata. Selain itu, beragam sosial media juga dapat dimanfaatkan sebagai sarana promosi desa wisata. Tidak hanya sosial media, tetapi tren tokoh panutan (influencer) juga menjadi peluang yang dapat diberdayakan sebagai sarana promosi desa wisata.

Threats: Ancaman merupakan salah satu faktor eksternal yang perlu dipertimbangkan pengelola Desa Wisata Brajan. Analisis terhadap faktor ini dianggap perlu agar pengelola dapat menghindari ancaman yang mungkin terjadi. Dari sisi ekonomi terdapat ancaman gagal bayar apabila pengelola mengikuti program Kredit Usaha Rakyat (KUR). Hal tersebut disebabkan karena tingkat kunjungan wisatawan masih fluktuatif. Kunjungan wisatawan tinggi ketika musim liburan (high season), sedangkan pada low season tingkat kunjungannya rendah. Adapun dari faktor lingkungan terdapat beberapa ancaman seperti kondisi kebersihan lingkungan dan terjadinya bencana alam. Desa Wisata Brajan berada di kawasan Kabupaten Sleman yang turut terkena dampak dari letusan Gunung Merapi. Hal tersebut dapat menjadi ancaman karena Gunung Merapi merupakan gunung dengan status aktif dan memiliki siklus letusan tertentu. Dampak dari letusan gunung menyebabkan penurunan kunjungan wisatawan. Selain itu, faktor pesaing juga menjadi ancaman di samping faktor lainnya seperti ekonomi, politik, sosial, budaya, dan lingkungan. Kompetitor Desa Wisata Brajan adalah desa wisata dengan karakteristik hampir sama contohnya Desa Wisata Gamplong yang juga berbasis kebudayaan berupa kerajinan tenun. Keberadaan pesaing menjadi ancaman karena dapat menarik target pasar dari Desa Wisata Brajan.

Matriks SWOT menunjukkan hasil 4 kategori strategi sebagai rekomendasi. Strategi SO mendorong Desa Wisata Brajan untuk menggunakan kekuatan yang dimiliki dalam memanfaatkan peluang. Strategi WO mengarahkan desa wisata ini untuk menetapkan harga bersaing dan meningkatkan kualitas sumber daya manusia. Strategi ST memberikan alternatif strategi untuk menggunakan kekuatan agar dapat mengatasi ancaman yaitu kompetitor. Lebih lanjut, strategi WT digunakan untuk meminimalkan kelemahan dan menghindari ancaman melalui inovasi proses pelayanan wisata. Kondisi internal dan eksternal Desa Wisata Brajan menunjukkan bahwa desa ini memiliki banyak kekuatan dan peluang yang belum diberdayakan. Berdasarkan kondisi tersebut maka strategi yang sesuai untuk diterapkan yaitu strategi SO. Strategi SO terdiri dari (1) mengembangkan produk wisata sesuai trend minat wisatawan, (2) memberdayakan tokoh panutan (influencer) sebagai sarana promosi melalui media sosial, dan (3) peningkatan kualitas dan kuantitas fasilitas.

Segmen pasar Desa Wisata Brajan adalah grup wisatawan berupa pelajar, karyawan suatu perusahaan, anggota organisasi tertentu, maupun wisatawan asing yang melakukan kegiatan wisata MICE (Meeting, Incentive, Conference, dan Exhibition) dalam hal ini biasanya insentive tourism. Perkembangan tren segmen tersebut mengarah kepada wisata berbasis edukasi dan pengalaman. Oleh sebab itu, Desa Wisata Brajan perlu mengembangkan produk wisata yang berbasis edukasi dan pengalaman. Selain pengalaman belajar membuat kerajinan bambu, produk budaya lainnya bisa dikemas sebagai produk wisata berbasis edukasi dan pengalaman. Contoh pengembangan produk tersebut misalnya adalah membuat kerajinan bambu dan hasilnya diberikan kepada wisatawan sebagai cinderamata, belajar menari tarian tradisional, belajar alat musik tradisional gamelan, outbond dan susur sungai, belajar membuat makanan khas tradisional, serta bersepeda keliling desa (morning cycling atau afternoon cycling). Desa Wisata Brajan juga dapat bekerja sama dengan influencer atau selebgram dengan kepribadian sesuai karakter tokoh panutan yang diharapkan dapat memengaruhi calon wisatawan untuk mengunjungi desa wisata ini. Hal tersebut diharapkan dapat menjadi sarana promosi sehingga meningkatkan jumlah kunjungan wisatawan. Fasilitas sebagai salah satu bentuk physical evidence juga perlu ditingkatkan kualitas dan kuantitasnya agar dapat mendukung kelancaran proses pelayanan jasa wisata kepada wisatawan. Desa Wisata Brajan dapat memperoleh alternatif pembiayaan melalui Kredit Usaha Rakyat. Peluang pembiayaan tersebut dapat dialokasikan untuk menambah jumlah fasilitas seperti toilet umum atau area parkir. Peningkatan kualitas fasilitas juga perlu dilakukan dengan perbaikan jalan desa.

\section{Pengembangan Bisnis Pariwisata Desa Wisata Brajan}

Gambar 3 menunjukkan matriks Business Model Canvas setelah mengalami pengembangan. Rekomendasi strategi berdasarkan hasil analisis SWOT disesuaikan dalam matriks Business Model Canvas untuk mengembangkan model bisnis pariwisata di Desa Wisata Brajan. Dengan demikian Desa Wisata Brajan dapat mengembangkan bisnisnya dan menjadi desa wisata kategori mandiri. 


\begin{tabular}{|c|c|c|c|c|}
\hline \multirow{2}{*}{$\begin{array}{l}\text { Kev partners: } \\
\text {-Dinas Pariwisata } \\
\text { Kabupaten } \\
\text { Sleman } \\
\text {-Jasa Raharja } \\
\text {-UMKM makanan } \\
\text { tradisional } \\
\text {-Perbankan } \\
\text {-Tourism } \\
\text { influencer }\end{array}$} & $\begin{array}{l}\text { Key activities: } \\
\text {-Perencanaan } \\
\text { layout alam } \\
\text { pedesaan } \\
\text {-Pembuatan } \\
\text { kerajinan bambu } \\
\text {-Pelatihan } \\
\text { pembuatan } \\
\text { kerajinan bambu } \\
\text {-Kegiatan outbond } \\
\text {-Pembuatan } \\
\underline{\text { makanan }} \\
\text { tradisional }\end{array}$ & \multirow{2}{*}{$\begin{array}{l}\text { Value Propositions: } \\
\text {-Something to see (suasana alam } \\
\text { pedesaan yang asri) } \\
\text {-Something to do (edukasi } \\
\text { pembuatan kerajikan bambu, } \\
\text { sensasi outbond di alam pedesaan, } \\
\text { makanan tradisional) } \\
\text {-Something to buy (kerajinan bambu, } \\
\text { makanan tradisional) } \\
\text {-Akses yang mudah } \\
\text {-Fasilitas memadai }\end{array}$} & $\begin{array}{l}\frac{\text { Costomer }}{\text { Relationships: }} \\
\text {-Media sosial } \\
\text {-Layanan grup } \\
\text { (pemandu) } \\
\text {-Tourism } \\
\underline{\text { influencer }}\end{array}$ & \multirow{2}{*}{$\begin{array}{l} \\
\text { Cusotemr } \\
\frac{\text { Segments: }}{\text {-Domestik }} \\
\text { (pelajar, } \\
\text { mahasiswa, grup, } \\
\text { MICE) } \\
\text {-Asing/ } \\
\text { mancanegara }\end{array}$} \\
\hline & $\begin{array}{l}\frac{\text { Key Resources: }}{\text {-Tangible (lahan }} \\
\text { pedesaan, } \\
\text { bangunan } \\
\text { pendukung, SDM, } \\
\text { bahan baku alami, } \\
\text { sumber daya } \\
\text { keuangan) } \\
\text {-Intangible (budaya } \\
\text { masyarakat, } \\
\text { keterampilan } \\
\text { membuat } \\
\text { kerajinan bambu) }\end{array}$ & & $\begin{array}{l}\text { Channels: } \\
\text {-Biro Perjalanan } \\
\text { Wisata }\end{array}$ & \\
\hline \multicolumn{2}{|c|}{$\begin{array}{l}\text { Cost Structure: } \\
\text {-Biaya operasional } \\
\text {-Upah tenaga kerja } \\
\text {-Biaya pemasaran } \\
\text {-Biaya pengembangan } \\
\text {-Biaya perawatan } \\
\text {-Biaya pembuatan kerajinan bambu }\end{array}$} & \multicolumn{3}{|c|}{$\begin{array}{l}\text { Revenue Streams: } \\
\text {-Penjualan paket wisata } \\
\text {-Penjualan tiket masuk kawasan wisata } \\
\text {-Jasa akomodasi } \\
\text {-Penjualan souvenir kerajinan tangan dari bambu } \\
\text {-Penjualan makanan dan minuman tradisional }\end{array}$} \\
\hline
\end{tabular}

Keterangan: underline (diciptakan), bold (ditingkatkan dan dikembangkan)

Gambar 3. Pengembangan Business Model Canvas Desa Wisata Brajan

Customer Segments: Segmen pasar Desa Wisata Brajan yang terdiri dari wisatawan domestik maupun asing baik FIT (Free Individual Traveler) atau group perlu ditingkatkan dan dikembangkan. Segmen pasar tersebut dapat dikembangkan pada wisatawan keluarga (family). Selain itu pengembangan segmen geografis juga perlu dilakukan dengan memperluas sebaran pasar. Wisatawan asing tidak hanya pada segmen Eropa tetapi juga Asia yaitu China, Jepang, dan Korea.

Value Propositions: Desa Wisata Brajan perlu meningkatkan produk paket wisata berbasis pengalaman dan edukasi sesuai perkembangan minat wisatawan (something to do). Produk baru berbasis pengalaman dan edukasi juga perlu diciptakan yaitu makanan atau minuman tradisional, contohnya paket menghias jajanan pasar dengan tampah atau besek, paket membuat jamu tradisional, atau paket makan malam kenduri. Lebih lanjut, pembiayaan dari Kredit
Usaha Rakyat dapat digunakan untuk meningkatkan kualitas dan kuantitas fasilitas serta aksesibilitas.

Channels: Desa Wisata Brajan dapat bekerja sama dengan biro perjalanan wisata luar daerah untuk meningkatkan jumlah saluran distribusi tidak langsung. Kunjungan ke instansi pendidikan (universitas dan sekolah) serta perusahaan perlu dilakukan untuk menciptakan saluran distribusi langsung.

Customer Relationship: Desa wisata ini perlu meningkatkan pemanfaatan media sosial untuk menjalin hubungan dengan wisatawan. Pengelola juga perlu bekerja sama dengan tourism influencer agar menciptakan relasi dengan wisatawan. Dengan demikian diharapkan tourism influencer tersebut dapat memotivasi calon wisatawan untuk berkunjung ke Desa Wisata Brajan. 
Revenue Streams: Pengembangan produk wisata diharapkan dapat meningkatkan pendapatan desa wisata dari penjualan paket wisata, tiket masuk kawasan, jasa penyewaan homestay, dan produk kerajinan tangan dari bambu (souvenir). Lebih lanjut, desa ini juga akan memperoleh pendapatan baru dari penjualan makanan dan minuman tradisional sebagai hasil pengembangan value proposition.

Key Activities: Aktivitas baru diciptakan seiring dengan pengembangan value proposition. Aktivitas tersebut yaitu pembuatan makanan dan minuman tradisional.

Key Resources: Sumber daya di Desa Wisata Brajan baik itu tangible dan intangible perlu dikembangkan untuk mendukung desa wisata ini menuju desa wisata mandiri.

Key Partnerships: Desa Wisata Brajan dapat menjalin kerjasama dengan UMKM makanan tradisional untuk mendukung pengembangan value proposition. Rekanan berupa perbankan juga diperlukan sebagai sumber pendanaan melalui Kredit Usaha Rakyat. Lebih lanjut, kerjasama dengan tourism influencer juga diperlukan sebagai sarana promosi dalam rangka meningkatkan kunjungan wisatawan.

Cost Structure: Adapun biaya yang dibutuhkan untuk menjalankan aktivitas di Desa Wisata Brajan juga meningkat sebagai dampak pengembangan komponen lainnya. Biaya operasional meningkat untuk menciptakan produk baru berupa makanan dan minuman tradisional. Biaya pemasaran dalam hal ini promosi meningkat untuk membayar jasa tourism influencer. Sedangkan biaya pengembangan fasilitas dan perawatan juga meningkat dalam rangka menambah jumlah fasilitas yang dimiliki.

\section{Implikasi Manajerial}

Hasil penelitian memberikan implikasi manajerial bagi Pokdarwis (Kelompok Sadar Wisata) di Desa Wisata Brajan untuk mengimplementasikan strategi dan model bisnis wisata dalam rangka menuju desa wisata kategori mandiri. Langkah yang dapat dilakukan oleh Pokdarwis yaitu mengamati perkembangan trend dari kebutuhan dan minat wisatawan kemudian mengembangkan produk wisata berdasarkan minat wisatawan. Selain itu, promosi melalui media sosial dan promosi melalui tourism influencer dapat diterapkan sebagai implementasi komunikasi pemasaran. Lebih lanjut, diperlukan kerja sama dengan para pemangku kepentingan untuk meningkatkan kualitas dan kuantitas fasilitas pendukung di destinasi.

\section{KESIMPULAN DAN SARAN}

\section{Kesimpulan}

Analisis terhadap faktor internal dan eksternal berdasarkan SWOT menghasilkan rekomendasi strategi SO yang dapat diterapkan oleh Desa Wisata Brajan. Rumusan strategi tersebut berpengaruh pada pemetaan model bisnis kanvas bahwa bisnis yang dijalankan saat ini memerlukan peningkatan di beberapa elemen seperti value proposition dan penciptaan nilai baru yaitu wisata berbasis pengalaman dan edukasi. Hal tersebut berdampak pada perluasan customer segment secara geografis sehingga diperlukan peningkatan channels melalui kerjasama dengan Biro Perjalanan Wisata dan penciptaan alternatif baru bagi customer relationship melalui tourism influencer. Peningkatan dan pengembangan value proposition juga harus diimbangi dengan peningkatan key resources melalui peningkatan kualitas dan kuantitas fasilitas pendukung serta bertambahnya key partners melalui kerjasama UMKM dan peningkatan partisipasi warga desa, serta menciptakan key activities yang baru seperti produk makanan atau minuman tradisional. Pengembangan bisnis tentu membutuhkan biaya tambahan sehingga memerlukan peningkatan cost structure. Penerapan strategi tersebut diharapkan dapat meningkatkan revenue streams dan menciptakan sumber-sumber pendapatan baru. Dengan demikian, hal tersebut akan mendorong Desa Brajan menjadi desa wisata yang mandiri.

\section{Saran}

Saran yang dapat direkomendasikan kepada Pokdarwis Desa Wisata Brajan yaitu diperlukan pengembangan produk yang ditawarkan pada wisatawan disesuaikan dengan perkembangan kebutuhan dan minat wisatawan. Pihak pengelola perlu untuk mempromosikan paket wisata melalui media yang sering diakses oleh calon wisatawan seperti media sosial dan menstimulasi sumber pengaruh personal seperti tourism influencer. Perbaikan fasilitas dan penambahan jumlah fasilitas juga perlu dilakukan dalam rangka meningkatkan value propositions. 


\section{DAFTAR PUSTAKA}

Abam EN. 2016. Marketing a potential tourism destination - a case study of Nsanakang in Eyumojock Subdivision. Journal of Tourism dan Hospitality 5(5). https://doi.org/10.4172/21670269.1000251

Andajani E, Widjaja FN, Prihatiningrum AE. 2017. Pengembangan potensi Desa Wisata melalui Analisa SWOT di Kecamatan Kalitidu Bojonegoro. Seminar Nasional Dan Gelar Produk (SENASPRO) 909-915.

Ciolac $\mathrm{R}$ et al. 2017. Management of a tourist village establishment in mountainous area through analysis of costs and incomes. Sustainability (Switzerland) 9(6): 1-18. https://doi. org/10.3390/su9060875

Departemen Kebudayaan dan Pariwisata. 2009. Panduan Pemasaran Pariwisata yang Bertanggungjawab (Responsible Tourism Marketing). Jakarta: Departemen Kebudayaan dan Pariwisata.

Dharasta YSMA, Dyahjatmayanti D, Nieamah KF. 2017. Analisis SWOT Desa Wisata di Kabupaten Sleman Yogyakarta. Jurnal Manajemen 7(2): $42-50$.

Dinas Kebudayaan dan Pariwisata, Ludens Tourism Space, dan STARS. 2016. Laporan Kegiatan Klasifikasi Desa Wisata Kabupaten Sleman Tahun 2016. Yogyakarta: Dinas Kebudayaan dan Pariwisata.

Ernawati NM, Sudarmini NM, Sukmawati NMR. 2017. Impacts of tourism in Ubud Bali Indonesia: A community-based tourism perspective. Journal of Physics: Conference Series 953(1-9). https:// doi.org/10.1088/1742-6596/953/1/012078

Giampiccoli A, Saayman M. 2018. Community-based tourism development model and community participation. African Journal of Hospitality, Tourism and Leisure 7(4): 1-27.

Hamzah AS, Irfan M. 2018. Analysis of tourism village. Jurnal Notariil, 3(1): 1-12. https://doi.org/http:// dx.doi.org/10.22225/jn.3.1.597.1-12

Koswaraputra DI, Sinaga BM, Andati T. 2019. Pengembangan bisnis media The Jakarta Post Digital. Jurnal Aplikasi Bisnis Dan Manajemen 5(2): 177-186. https://doi.org/10.17358/ jabm.5.2.177

Kotler P, Keller KL. 2018. Manajemen Pemasaran Edisi Kedua Belas Jilid 1 (12th ed.). Jakarta: Indeks.
Kurniasih, Nihayah DM, Sudibyo SA, Winda FN. 2018. Tourism village model based on local indigenous: case study of Nongkosawit Tourism Village, Gunungpati, Semarang. E3S Web of Conferences 31. https://doi.org/10.1051/e3sconf/20183109011 Kusrini E. 2017. Strategy of tourist village development in Nongkosawit Sub-District, Gunungpati District, Semarang City. Economics Development Analysis Journal 6(2): 137-146.

Mustika A, Aditya MK. 2018. SWOT Analysis of rural tourism development : Case Study of Kampung Tajur, Purwakarta. Advances in Economics, Business and Management Research (AEBMR) 52: 19-28.

Nasehi, S., dan Allahyari, H. 2017. Assessment of rural tourism using SWOT analysis ( Case Study: Masouleh village, Gilan, Iran ). International Journal of Engineering Research And Advanced Technology (IJERAT) 3(5): 8-21.

Noor S. 2014. Penerapan Analisis SWOT Dalam Menentukan Strategi Pemasaran Daihatsu Luxio di Malang (Studi Kasus Pada PT. Astra International Tbk.-Daihatsu Malang). Jurnal INTEKNA 16(2): 102 - 209.

Pramanik PD, Widyastuti N. 2017. Rural Tourism Destination Strategy through SWOT Analysis in Cibuntu Village - Indonesia. ASEAN Tourism Research Association Conferen (ATRC): 1-9.

Rahardjo B, Hasbullah R, Taqi FM. 2019. Coffee shop business model analysis. Integrated Journal of Business and Economics 3(2): 140. https://doi. org/10.33019/ijbe.v3i2.153

Susyanti DW. 2013. Potensi Desa Melalui Pariwisata Pedesaan. Ekonomi Dan Bisnis, 12(1): 33-36.

Triyanto, Iwu CG, Musikavanhu TB, Handayani RD. 2018. Rural tourism as a way to build Economic Independence. African Journal of Hospitality, Tourism and Leisure 7(4): 1-11.

Vladi E. 2014. Tourism Development Strategies, SWOT analysis and improvement of Albania's image. European Journal of Sustainable Development 3(1): 167-178. https://doi.org/10.14207/ ejsd.2014.v3n1p167

Widyaningsih H. 2016. Analisis swot dan promosi kerajinan bambu Desa Wisata Brajan Kabupaten Sleman Yogyakarta. Khasanah Ilmu - Jurnal Pariwisata Dan Budaya 3(2): 1-10.

Zhang X. 2012. Research on the development strategies of rural tourism in suzhou based on swot analysis. Energy Procedia 16: 1295-1299. https://doi. org/10.1016/j.egypro.2012.01.207 